\title{
The soluble tumor necrosis factor receptor 1 as a potential early diagnostic and prognostic markers in intensive care unit patients with severe infections
}

\author{
MARTA STELMASIAK ${ }^{1,2}$, MAEGORZATA MIKASZEWSKA-SOKOLEWICZ3, \\ GRZEGORZ NIEWINSSKI ${ }^{4}$ BARBARA-JOANNA BAEAN ${ }^{1}$, ROBERT SŁOTWIŃSKI \\ ${ }^{1}$ Department of Immunology, Biochemistry and Nutrition, Medical University of Warsaw, Warsaw, Poland \\ ${ }^{2}$ Faculty of Medical and Health Sciences, Kazimierz Pulaski University of Technology and Humanities in Radom, Poland \\ ${ }^{3} 1^{\text {st }}$ Department of Anesthesiology and Intensive Care, Medical University of Warsaw, Warsaw, Poland \\ ${ }^{4} 2^{\text {nd }}$ Department of Anesthesiology and Intensive Care, Medical University of Warsaw, Poland
}

\begin{abstract}
Introduction: Substantial causes of high mortality (30-50\%) of people with severe infections treated in intensive care units (ICUs) are still inadequately known in terms of mechanisms and insufficient diagnostic tools for immune responses in sepsis.

Material and methods: The aim of this study was to establish a practical value of determining the concentration of chosen proteins (by ELISA) in peripheral blood as potential in early diagnostics of severe infections, paying special attention to their prognostic values.

Results: In 163 patients treated in ICUs, changes were assessed in the concentration of chosen proteins relating to the TLR4 receptor signalling pathway, including its effectors of pro- and anti-inflammatory cytokines (IL-1Ra, TNF- $\alpha$, sTNFR1, IL-6, IL-10, sTLR4, MyD88, TNFAIP3/A20, HSP70, and $H M G B 1)$. In the analysis of changes in the process of immune response in severely ill patients with and without infections, a significantly higher concentration of STNFR1 was observed in patients with infections than those who deceased. In the ROC curves tests, it was noted that an assessment of the concentration of STNFR1 proteins $(A U C=0.686$ and cut-off point $=24.841 \mathrm{pg} / \mathrm{ml})$ was a particularly efficient tool, with prognostic significance in patients with infections.

Conclusions: In other patients treated in an ICU, the efficiency of determining IL-6 (AUC=0.736) was confirmed and at the same time, the effectiveness of this cytokine in predicting death in cases with infections was excluded. The results of the present study are encouraging, suggesting the benefits of undertaking multi-center clinical trials, which consider monitoring sTNFR1 in different groups of patients with infections treated in intensive care units.
\end{abstract}

Key words: biomarkers, sepsis, innate immunity, ICU, prognostic value, sTNFR1.

(Cent Eur J Immunol 2020; 45 (2): 160-169)

\section{Introduction}

The latest directives regarding diagnosing and differentiation of severe infections define sepsis as a life-threatening organ failure, caused by a dis-regulated response (immunological and non-immunological) of a host to an infection. Septic shock is a variation of sepsis, in which deteriorated circulatory, cellular, and metabolic disorders relate to a higher risk of death than in the case of sepsis alone. Presently, it is considered that sepsis is associated with simultaneous activation of pro- and anti-inflammatory processes and also, apart from modifications in the immune system, changes in the cardiovascular, nervous, endocrine, and coagulation systems as well as alterations in metabolic pathways [1]. Severe infections, sepsis, and septic shock are causes of hospitalization in approximately $40 \%$ of patients in intensive care units (ICUs). Mortality, despite constant progress in therapy, remains high (with global 30-50\% of cases [2-4]) and in Poland, it occurs in $46 \%$ of patients [5]. Substantial causes of high mortality in people with severe infections are still poorly known in terms of mechanisms, which regulate immune responses in sepsis. In clinical practice, the mortality in severe infections is predicted using acute physiology and chronic health evaluation

Correspondence: Marta Stelmasiak, Department of Immunology, Biochemistry and Nutrition, Medical University of Warsaw, 3 Oczki St., 02-007 Warsaw, Poland, e-mail: marta_jankowska@vp.pl Submitted: 5.04.2019; Accepted: 10.10.2019 
II (APACHE II) scale and sequential organ failure assessment (SOFA) score, evaluating the condition of a patient based on clinical and laboratory parameters. Recently in ICUs, chosen cytokines related to early immune response to infections as diagnostic and prognostic indicators are used. However, the prognostic values of cytokines and the correlation of their concentration with the occurrence of severe complications and mortality have not been fully established; there is still a deficiency in norms. So far, the question concerning the quantitative relation between the concentration of cytokines and the physiological pathological reaction of the immune system to an injury and infection remains $[6,7]$. Another problem that increases the mortality and requires further research is the early diagnostics of deteriorating immunosuppression and malnutrition (catabolism, sarcopenia, and marasmus) in the process of compensatory anti-inflammatory response syndrome (CARS) and persistent inflammation, immunosuppression, and catabolism syndrome (PICS) in patients treated in ICUs [8-10].

It should be assumed that early diagnostics of immune disorders and better understanding of the increasing disturbance of immune response in some patients with developing sepsis, would allow therapeutic activities to predict organ injuries, for example, an excessive activation of cells belonging to the immune system. Till now, more than 170 biomarkers of sepsis have been examined [4, 11], which indicated problems related to complex mechanisms of acute infections. Most of the examined markers have no use in clinical practice and they do not contribute to decreasing mortality, mostly due to insufficient diagnostic and prognostic values as well as specificity in the detection of severe infections. It is assumed that a higher diagnostic efficiency can result from immune markers connected to the innate response of infection, and also from an explanation of relationships between pro-inflammatory reaction and anti-inflammatory reaction using markers for defining the phase of immune reaction [12-14]. Diagnostic and prognostic usefulness of the chosen immunological biomarkers of sepsis and also the pro-inflammatory cytokines (interleukin [IL]-6 - IL-6, IL-8, tumor necrosis factor $\alpha-\mathrm{TNF}-\alpha$ ) and anti-inflammatory cytokines (IL-10) were described in detail by Biron et al., who at the same time indicated the necessity to further exploration of effective markers of sepsis [15]. In this regard, certain potential is seen in the possibility of regulating the pathway of toll-like receptors 4 (TLR4). It is well-known that the TLR4 receptors undergo expression in the cell membrane of leucocytes, on endothelial cells, in the intestinal mucous membrane, on dendritic cells, or neoplastic cells. The main factors responsible for their development are lipopolysaccharide (LPS) present in the cell membrane of bacteria, high mobility group box 1 protein (HMGB1), and heat shock proteins 70 (HSP70). The pathway of receptors TLR4 is composed of a few adaptor proteins, such as myeloid differentiation primary response 88 (MyD88). There is a possibility of natural autoregulation of the pathway by activity of inhibitor proteins, including tumor necrosis factor $\alpha$-induced protein 3 (TNFAIP3/A20), also known as A20 protein [16]. In order to decrease a high mortality in groups of critically ill patients with infections, efforts to block the TLR4 receptors (e.g. TLR4 receptor blockade by antagonists eritoran-E5564 [17] or resatorvid-TAK242 [18]) were made. They aimed at limiting the inflammatory response, because the effectors of this pathway are pro- and anti-inflammatory cytokines (e.g., TNF- $\alpha$, IL-6, IL-10) [19]. However, the results of clinical tests did not confirm the expected therapeutic efficiency.

In clinical tests, in the context of diagnostic value of cytokines, it was concluded that in patients with severe infections, the concentration of cytokines was higher than in non-septic patients [11]. It was also found that IL-6 and IL-8 were effective in early and later diagnostics of sepsis in infants [20]. Regarding prognostic values of cytokines, it was proven that there was a correlation between concentrations of IL- 6 and IL- 8 and severity and mortality of a disease [21]. Concentrations of TNF- $\alpha$ and IL-10 were higher in patients who deceased [22, 23]. It is known that clinical requirements for modern biomarkers of sepsis are constantly being increased. They do not concern only early diagnostics of acute infections and anticipating the occurrence of clinical symptoms, but also precise assessment of phase and exacerbation of dysfunctions of immune response that are associated with an infection. The fundamental importance appears in differentiating between a physiological response to an injury and infection, and a pathological reaction, which would allow for early assessment of the risk of severe organ complications that increase mortality.

The aim of this study was to assess disorders in innate immune response (pro-, anti- inflammatory, and antibacterial) in severely ill patients with infections treated in ICUs. Furthermore, we attempted to determine the practical value of assessing the concentration of chosen proteins in peripheral blood (IL-1 receptor antagonist - IL-1Ra, TNF- $\alpha$, soluble tumor necrosis factor receptor 1 - sTNFR1, IL-6, IL-10, soluble toll-like receptor 4 - sTLR4, MyD88, TNFAIP3/A20, HSP70, HMGB1) as potential markers with crucial importance in early diagnostics of severe infections, which increase mortality, paying special attention to their prognostic values.

\section{Material and methods}

\section{Patients and healthy donors}

In total, 163 patients treated in ICUs of the $1^{\text {st }}$ and $2^{\text {nd }}$ Clinic of Anesthesiology and Intensive Therapy of Warsaw Medical University (average age, $57 \pm 18 ; 116$ males, 47 females) in the years 2014-2018 were qualified for the study. Among the 163 patients, $75(46 \%)$ were diagnosed with severe infections according to the criteria of Ameri- 
can College of Chest Physicians/Society of Critical Care Medicine (ACCP/SCCM), which included those with diagnosed sepsis $-51(31 \%)$, and those with diagnosed septic shock - 24 (15\%). The diagnosis of severe infections was based on clinical criteria, with additional suspected or confirmed infection in the case of sepsis, and other organ disfunction in the case of septic shock [24-26]. Microbiological cultures in patients with severe infections revealed mainly Gram-negative bacteria (especially Pseudomonas aeruginosa, Acinetobacter baumannii, Klebsiella pneumoniae, Escherichia coli), rarely Gram-positive bacteria (Staphylococcus spp. Enterococcus faecium, and Streptococcus spp.), and in few cases, fungi strains (Candida spp.) were found. In 5 patients, the microbiological analysis did not confirm an infection. The material for microbiological tests was collected according to a routine procedure. Positive results were most often obtained from respiratory tract (50\%), then abdominal cavity/gastrointestinal tract, skin, blood, or urine. The remaining $88(54 \%)$ patients had no coexisting severe infections. Apart from severe infections, the main cause of hospitalization in ICU were multi-organ injuries resulting from accidents. In the entire group, $86(53 \%)$ patients required mechanical ventilation and $50(30.7 \%)$ deaths were recorded. In 22 cases, death was reported in the course of severe infection, and in 28 cases, death was registered in the group of patients who were not diagnosed with severe infection. The most common cause of death in this group was sudden circulatory arrest or injuries from traffic accidents. The percentage of surgical patients in the analyzed group was insignificant, due to the existence of specialized post-surgical ward in the hospitals participating in the research. Severity of condition and the risk of death was assessed using APACHE II scale (median for the entire group was 26 points; range, 5-51 points). During their stay in an ICU, the entire group was monitored regarding the course of illness and mortality within the period of 28 days.

The research did not include patients above the age of 80, after chemo- and radiotherapy, with diabetes, chronic liver, and kidney diseases, after transplants, under immunosuppressive treatment, and those regularly taking steroids, or non-steroid anti-inflammatory medications.

The control group were 48 healthy volunteers in similar age and sex categories, from whom peripheral blood (plasma) was sampled for immunological tests.

The research was approved by the Bioethical Commission of the Warsaw Medical University (KB/149/2008). Each patient agreed to the tests and allowed the access to their medical record. All procedures were in accordance with the Helsinki Declaration.

\section{Determination of protein concentrations}

The peripheral blood for immunological tests was sampled within the first day after the admission to the ICU.
For examining concentration of chosen proteins (IL-1Ra, TNF- $\alpha$, sTNFR1, IL-6, IL-10, sTLR4, MyD88, TNFAIP3/ A20, HSP70, HMGB1) in the plasma of peripheral blood, a commercial set with ELISA (R\&D Systems: TNF- $\alpha$, sTNFR1, Il-1Ra, IL-6, IL-10, HSP70, HMGB1; EIAab: sTLR4, Myd88, A20) was used, according to the manufacturer's instruction. Plasma was obtained from venous blood sampled for heparin. Blood samples were centrifuged (2,000 rpm for 30 minutes), plasma was isolated, and then frozen/stored in the temperature of $-80^{\circ} \mathrm{C}$ for further use. The lower limit of the test sensitivity was $0.5 \mathrm{pg} / \mathrm{ml}$ for TNF- $\alpha, 0.70 \mathrm{pg} / \mathrm{ml}$ for IL-6, $3.9 \mathrm{pg} / \mathrm{ml}$ for IL-10, $2.2 \mathrm{pg} / \mathrm{ml}$ for IL-1 Ra, $0.43 \mathrm{pg} / \mathrm{ml}$ for $\mathrm{sTN}$ FR1, $0.625 \mathrm{pg} / \mathrm{ml}$ for sTLR4, $0.156 \mathrm{pg} / \mathrm{m}$ for MyD881, $0.312 \mathrm{pg} / \mathrm{ml}$ for A20, $6.79 \mathrm{ng} / \mathrm{ml}$ for HSP70, $18.75 \mathrm{pg} / \mathrm{ml}$ for HMGB1. Reading of the ELISA test was conducted using a spectrophotometer DIALAB ELX 808 and software Gen51.10, at the wavelength $\lambda=450 \mathrm{~nm}$. Concentration of the examined proteins was assessed by comparing the obtained absorbance values, with a calibration curve prepared by determining the absorbance of samples with significant concentration. The results are presented as concentration medians in $\mathrm{pg} / \mathrm{ml}$.

\section{Statistical analysis}

For the statistical research, the programme Statistica 13.1. was used. For comparison of the researched group and the control group, the group in which a death or survival occurred, and the groups where the cause of hospitalization were severe infections or other illnesses, the $U$ Mann-Whitney test was utilized. The receiver operating characteristic curves (ROCs) were applied to determine the sensitivities and specificities for cytokine and other proteins measurements. To evaluate the ability of each protein level to distinguish survivors from non-survivors and to predict the evolution of organ dysfunction [27], the area under the curve and the optimal cut-off values were calculated. The correlation between age and concentration of determined proteins was analyzed with the $\rho$-Spearman test; $p$ values $<0.05$ were considered as statistically significant.

\section{Results}

\section{Diagnostics of immune disorders}

The majority of parameters analyzed in the entire group of patients showed significant deviation from the norm. The highest values were observed for concentrations of sTNFR1, IL-1Ra, and IL-6 in plasma. In comparison with the norm, concentrations of sTNFR1 were almost 45 times higher, and for IL-6, even 32 times higher. Significantly increased concentrations were also recorded in testing of TNF- $\alpha$ and sTLR4, whereas concentration val- 
ues of MyD88 and TNFAIP3/A20 strongly decreased in comparison with the norm (for all parameters, $p<0.05$ ). Concentrations of other proteins (IL-10, HSP70, and HMGB1) did not deviate from the norm. Similar changes in concentration of the proteins determined in plasma were observed in the sub-group of patients with severe infections (with diagnosed sepsis or septic shock). In the patients with severe infections as compared to the control group, significantly increased concentrations were observed in most cases of the examined proteins (TNF- $\alpha$, IL-1Ra, IL-6, sTLR4, sTNFR1), excluding the proteins of antibacterial response signalling pathway (Myd88 and A20), which were significantly decreased (for all parameters, $p<0.05)$. Lack of significant differences between the group of patients with severe infections and the control group was observed in concentrations of IL-10, HSP70, and HMGB1. Analysis of the sub-group of patients without severe infections, who were hospitalized in the ICU for other reasons, showed significant increase in concentration of TNF- $\alpha$, IL-6, sTNFR1, IL-1Ra, and sTLR4 $(p<0.05)$, and decreased concentrations of MyD88 and A20 in comparison with the norm $(p<0.05)$. Concentrations of HSP70 and HMGB1 in the compared groups did not deviate from the accurate values. The values of medians and ranges of concentrations $(\mathrm{pg} / \mathrm{ml})$ of the examined proteins are presented in Table 1.

Further analysis of the median $(\mathrm{pg} / \mathrm{ml})$ concentration of the examined proteins in the subgroup of patients with severe infections in comparison with the subgroup of patients treated in ICU for other reasons without infections, showed that concentration of sTNFR1 in patients with severe infections was more than 25 times higher, and concentration of IL-1Ra was 1.5 times higher in patients with severe infections, whereas concentration of the A20 protein was more than 1.6 times lower. However, from all studied parameters, significantly higher concentrations were recorded only in the cases of sTNFR1 proteins $(p=0.0000)$ (Fig. 1) and IL-10 ( $p=0.0081)$ in patients with severe infections (with diagnosed sepsis or septic shock) in comparison with patients without severe infections. In evaluation of the same groups, significantly lower concentration of STLR4 $(p=0.0002)$ was observed in the group with infections. For all determined proteins, no statistically important differences were recorded between the group of patients with sepsis and patients with septic shock.

Table 1. The values of medians and ranges of concentrations $(\mathrm{pg} / \mathrm{ml})$ for the studied immunological parameters with division to subgroups

\begin{tabular}{|c|c|c|c|c|c|c|c|c|c|}
\hline $\begin{array}{l}\text { Immunological } \\
\text { parameters }\end{array}$ & $\begin{array}{l}\text { Whole group } \\
\quad(n=163)\end{array}$ & $\begin{array}{l}\text { Control group } \\
\quad(n=48)\end{array}$ & $p$-value & $\begin{array}{c}\text { Severe } \\
\text { infection } \\
(n=75)\end{array}$ & $\begin{array}{c}\text { Without } \\
\text { infection } \\
(n=88)\end{array}$ & $p$-value & $\begin{array}{l}\text { Survival } \\
(n=113)\end{array}$ & $\begin{array}{r}\text { Decease } \\
(n=50)\end{array}$ & $p$-value \\
\hline IL-6 & $\begin{array}{l}47.91 \text { range: } \\
0.04-960.49\end{array}$ & $\begin{array}{l}1.50 \text { range: } \\
0.00-613.05\end{array}$ & 0.0000 & $\begin{array}{l}47.80 \text { range: } \\
1.43-423.16\end{array}$ & $\begin{array}{l}49.37 \text { range: } \\
0.04-960.49\end{array}$ & $>0.05$ & $\begin{array}{l}46.61 \text { range: } \\
0.04-619.75\end{array}$ & $\begin{array}{l}53.76 \text { range: } \\
8.40-960.49\end{array}$ & 0.0016 \\
\hline sTNFR1 & $\begin{array}{c}8,992.60 \\
\text { range: } 21.31- \\
47,921.30\end{array}$ & $\begin{array}{c}200.32 \text { range: } \\
27.11-4,864.50\end{array}$ & 0.0000 & $\begin{array}{c}20,833.70 \\
\text { range: } 251.78- \\
47,921.30\end{array}$ & $\begin{array}{c}815.63 \text { range: } \\
21.310- \\
46,794.50\end{array}$ & 0.0000 & $\begin{array}{c}10,353.00 \\
\text { range: } 21.31- \\
45,572.80\end{array}$ & $\begin{array}{c}25,665.65 \\
\text { range: } \\
9,651.30- \\
47,921.30\end{array}$ & 0.0039 \\
\hline $\mathrm{TNF}-\alpha$ & $\begin{array}{l}25.41 \text { range: } \\
1.99-491.85\end{array}$ & $\begin{array}{l}13.29 \text { range: } \\
0.36-321.96\end{array}$ & 0.0000 & $\begin{array}{l}27.18 \text { range: } \\
2.62-194.98\end{array}$ & $\begin{array}{l}24.38 \text { range: } \\
2.00-491.85\end{array}$ & $>0.05$ & $\begin{array}{l}24.69 \text { range: } \\
2.00-491.85\end{array}$ & $\begin{array}{l}27.78 \text { range: } \\
3.54-266.10\end{array}$ & $>0.05$ \\
\hline MyD88 & $\begin{array}{c}0.00 \text { range: } \\
0.00-14,712.00\end{array}$ & $\begin{array}{c}476.00 \text { range: } \\
0.00-19,168.00\end{array}$ & 0.0000 & $\begin{array}{c}0.00 \text { range: } \\
0.00-13,536.00\end{array}$ & $\begin{array}{c}0.00 \text { range: } \\
0.00-14,712.00\end{array}$ & $>0.05$ & $\begin{array}{c}0.00 \text { range: } \\
0.00- \\
14,712.00\end{array}$ & $\begin{array}{c}0.00 \text { range: } \\
0.00- \\
11,372.00\end{array}$ & $>0.05$ \\
\hline TNFAIP3/A20 & $\begin{array}{l}1.35 \text { range: } \\
0.14-20.98\end{array}$ & $\begin{array}{l}5.20 \text { range: } \\
0.06-20.50\end{array}$ & 0.0007 & $\begin{array}{l}1.14 \text { range: } \\
0.23-15.44\end{array}$ & $\begin{array}{l}1.92 \text { range: } \\
0.14-20.98\end{array}$ & $>0.05$ & $\begin{array}{l}3.14 \text { range: } \\
0.00-20.98\end{array}$ & $\begin{array}{l}5.51 \text { range: } \\
0.00-16.94\end{array}$ & $>0.05$ \\
\hline IL-1Ra & $\begin{array}{c}616.57 \text { range: } \\
104.48- \\
4,200.00\end{array}$ & $\begin{array}{l}387.42 \text { range: } \\
9.74-2,665.70\end{array}$ & 0.0117 & $\begin{array}{c}900.38 \text { range: } \\
135.54- \\
4,200.00\end{array}$ & $\begin{array}{c}\text { 589.24 range: } \\
104.48-3,999.36\end{array}$ & $>0.05$ & $\begin{array}{c}589.24 \text { range: } \\
104.48- \\
4,145.01\end{array}$ & $\begin{array}{c}2,439.78 \\
\text { range: } 135.54- \\
4,200.00\end{array}$ & $>0.05$ \\
\hline IL-10 & $\begin{array}{c}0.00 \\
\text { range: } 0.00- \\
918.69\end{array}$ & $\begin{array}{c}0.00 \\
\text { range: } 0.00- \\
21.77\end{array}$ & $>0.05$ & $\begin{array}{c}0.00 \text { range: } \\
0.00-918.69\end{array}$ & $\begin{array}{c}0.00 \text { range: } \\
0.00-339.41\end{array}$ & 0.0081 & $\begin{array}{c}0.00 \text { range: } \\
0.00-918.69\end{array}$ & $\begin{array}{c}7.50 \text { range: } \\
0.00-339.41\end{array}$ & 0.0217 \\
\hline sTLR4 & $\begin{array}{c}0.47 \text { range: } \\
0.45-1.10\end{array}$ & $\begin{array}{c}0.46 \text { range: } \\
0.45-0.55\end{array}$ & 0.0000 & $\begin{array}{c}0.46 \text { range: } \\
0.45-1.10\end{array}$ & $\begin{array}{c}0.48 \text { range: } \\
0.46-0.55\end{array}$ & 0.0002 & $\begin{array}{c}0.47 \text { range: } \\
0.45-1.10\end{array}$ & $\begin{array}{c}0.46 \text { range: } \\
0.45-0.50\end{array}$ & $>0.05$ \\
\hline HSP70 & $\begin{array}{l}0.10 \text { range: } \\
0.00-11.81\end{array}$ & $\begin{array}{c}0.22 \text { range: } \\
0.00-2.68\end{array}$ & $>0.05$ & $\begin{array}{c}0.09 \text { range: } \\
0.03-1.29\end{array}$ & $\begin{array}{l}0.10 \text { range: } \\
0.00-11.81\end{array}$ & $>0.05$ & $\begin{array}{c}0.08 \text { range: } \\
0.00-2.13\end{array}$ & $\begin{array}{c}0.25 \text { range: } \\
0.00-1.81\end{array}$ & 0.0165 \\
\hline HMGB1 & $\begin{array}{c}0.00 \text { range: } \\
0.00-3.65\end{array}$ & $\begin{array}{c}0.00 \text { range: } \\
0.00-3.88\end{array}$ & $>0.05$ & $\begin{array}{c}0.00 \text { range: } \\
0.00-0.00\end{array}$ & $\begin{array}{c}0.00 \text { range: } \\
0.00-3.65\end{array}$ & $>0.05$ & $\begin{array}{c}0.00 \text { range: } \\
0.00-3.65\end{array}$ & $\begin{array}{c}0.00 \text { range: } \\
0.00-0.97\end{array}$ & $>0.05$ \\
\hline
\end{tabular}




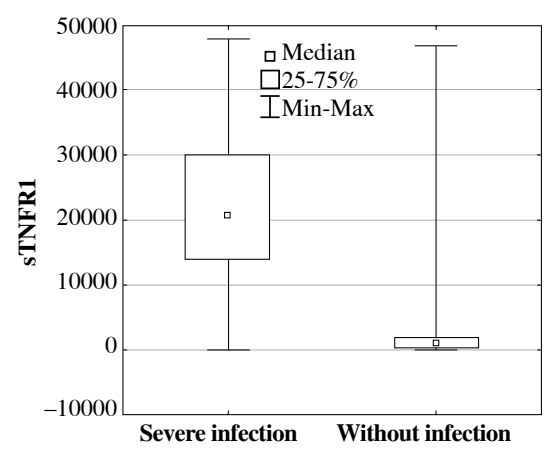

Fig. 1. The soluble tumor necrosis factor receptor 1 (sTNFR1) serum concentrations (median, min-max, pg/ml) in ICU patients with and without severe infections

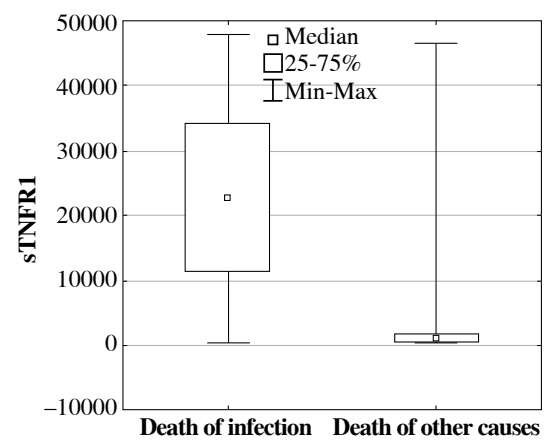

Fig. 4. The soluble tumor necrosis factor receptor 1 (sTNFR1) serum concentrations (median, min-max, pg/ml) in ICU patients who deceased due to severe infections, in comparison with deceased patients due to other causes
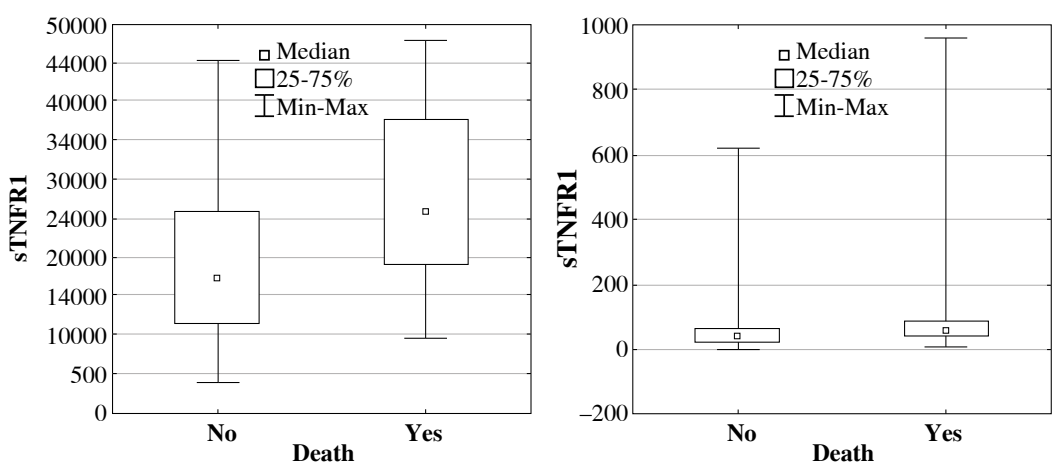

Fig. 2. The soluble tumor necrosis factor Fig. 3. Interleukin 6 (IL-6) serum conreceptor 1 (sTNFR1) serum concentrations centrations (median, min-max, pg/ml) (median, min-max, pg/ml) in ICU patients in ICU patients who survived or dewho survived or deceased during their treat- ceased during their treatment in ICU ment in ICU
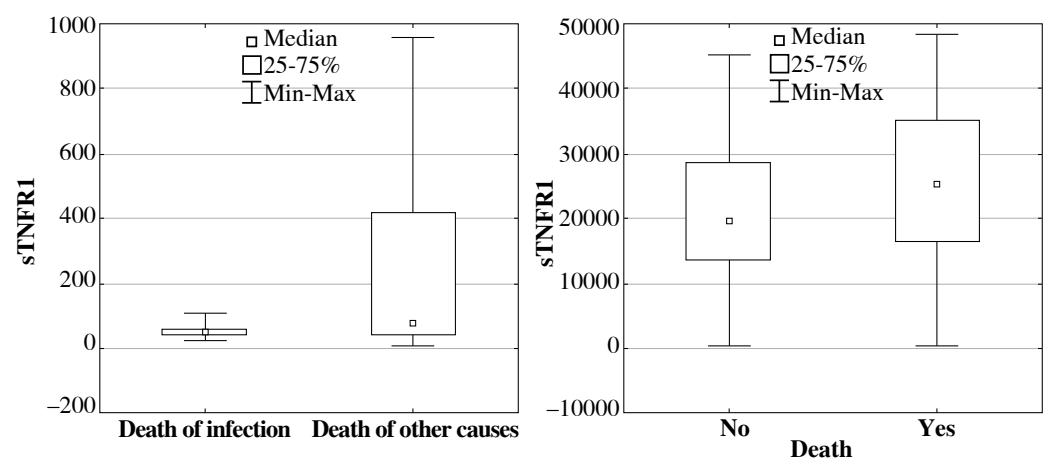

Fig. 5. Interleukin 6 (IL-6) serum con- Fig. 6. The soluble tumor necrosis faccentrations (median, min-max, pg/ml) tor receptor 1 (sTNFR1) serum conin ICU patients who deceased in the centrations (median, min-max, pg/ml) course of severe infections in compar- in ICU patients with severe infections ison with patients who deceased from who survived or deceased other causes

\section{Prognostic value of chosen proteins}

To assess prognostic value of determined proteins, their concentrations were compared between the groups of patients who survived and deceased during their treatment in ICU. In deceased patients, significantly higher concentrations (medians in $\mathrm{pg} / \mathrm{ml}$ ) were observed in following proteins: sTNFR1, IL-6, IL-10, and HSP70 in comparison with patients who survived (Table 1, Figs. 2 and 3 ).

As a result of further analysis, significant differences were observed in concentration of proteins STNFR 1 and IL-6 in deceased patients due to severe infections when compared with deceased patients due to other causes. It was observed that the concentration of protein sTNFR1 in septic patients who deceased was significantly high $(22,295.85 \mathrm{pg} / \mathrm{ml} ; p=0.00001)$, whereas the concentration of IL-6 (47.66 pg/ml; $p=0.0216)$ was significantly lower in comparison with deceased patients who were not diagnosed with severe infections: $730.11 \mathrm{pg} / \mathrm{ml}$ for sTNFR1 and $75.99 \mathrm{pg} / \mathrm{ml}$ for IL-6 (Figs. 4 and 5).

Moreover, it was observed that in the subgroup of deceased patients with severe infections, the level of protein sTNFR1 concentrations was significantly higher $(26,114.80 \mathrm{pg} / \mathrm{ml} ; p=0.0342)$ compared with the group of septic patients who survived (20,232.00 pg/ml) (Fig. 6).

\section{Results of ROC curves analysis}

To evaluate the risk of severe complications and death based on the examined concentrations of proteins, analyses of ROC curves were conducted for all proteins. In the entire group of patients treated in ICU, the ROC analysis showed AUC $=0.711(0.91,0.48)$ for sTNFR1 with the cut-off point of $16,367.6 \mathrm{pg} / \mathrm{ml}, \mathrm{AUC}=0.680(0.46,0.88)$ 

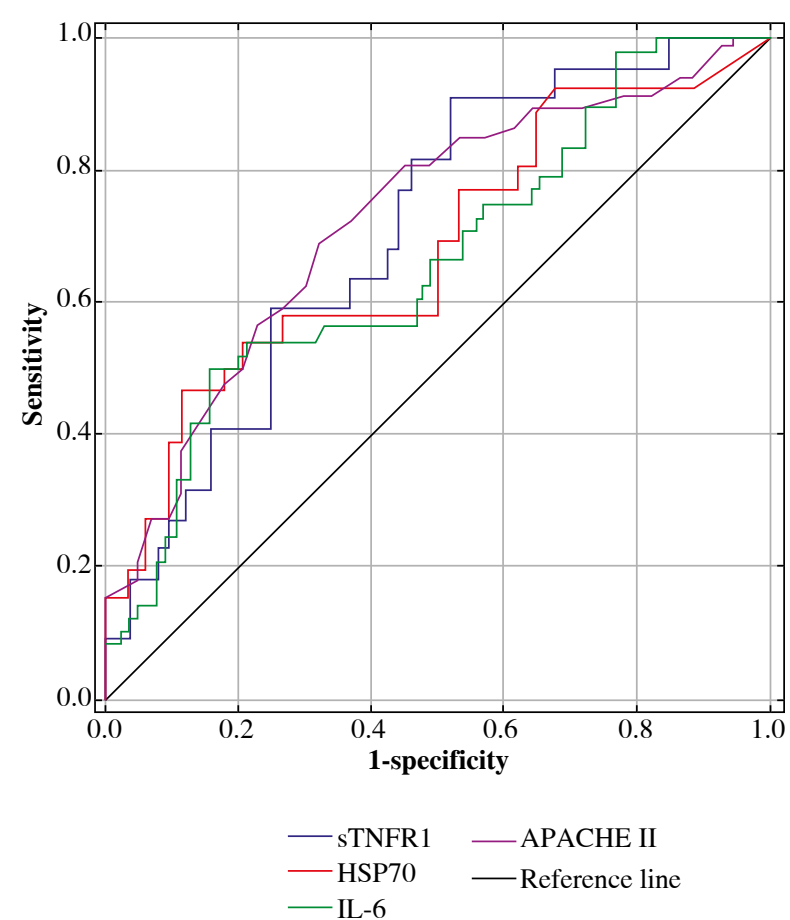

Fig. 7. ROC curves for chosen parameters (APACHE II, sTNFR1, HSP70, IL-6, pg/ml) in the patients treated in ICU

for HSP70 with the cut-off point equal to $0.347 \mathrm{pg} / \mathrm{ml}$, AUC $=0.664(0.50,0.85)$ for IL-6 with the cut-off point of $54.99 \mathrm{pg} / \mathrm{ml}$. For the remaining proteins, the analysis of ROC curves did not have significant prognostic importance. As resulted from additional analysis of ROC curves for APACHE II in the examined group of patients, it was observed that $\mathrm{AUC}=0.726(0.69,0.68)$ and the cut-off point was 27 (Fig. 7).

Analysis of ROC curves was also conducted for the group of patients with severe infections and in the group without severe infections. Analysis of the ROC curve for the group with infections, for protein sTNFR1 was AUC $=0.686(0.63,0.74)$ and the cut-off point was $24,841 \mathrm{pg} /$ $\mathrm{ml}$. In the same group, the AUC for APACHE II was 0.782 $(0.95,0.51)$, and the cut-off point was 25 (Fig. 8).

In the group of patients who were not diagnosed with infections, the analysis of ROC curves revealed that AUC $=0.736(0.69,0.75)$ for IL- 6 with the cut-off point equal to $52.53 \mathrm{pg} / \mathrm{ml}$, and AUC $=0.692(0.48,0.88)$ for protein HSP70 with the cut-off point equal to $0.35 \mathrm{pg} / \mathrm{ml}$. In the same group, the AUC for APACHE II was 0.695 (0.64, 0.75 ) and the cut-off point was 28 .

The analysis of correlation between age of patients and concentration of determined proteins showed low, vital correlation only for MyD88 ( $r=0.3084 ; p=0.0001)$.

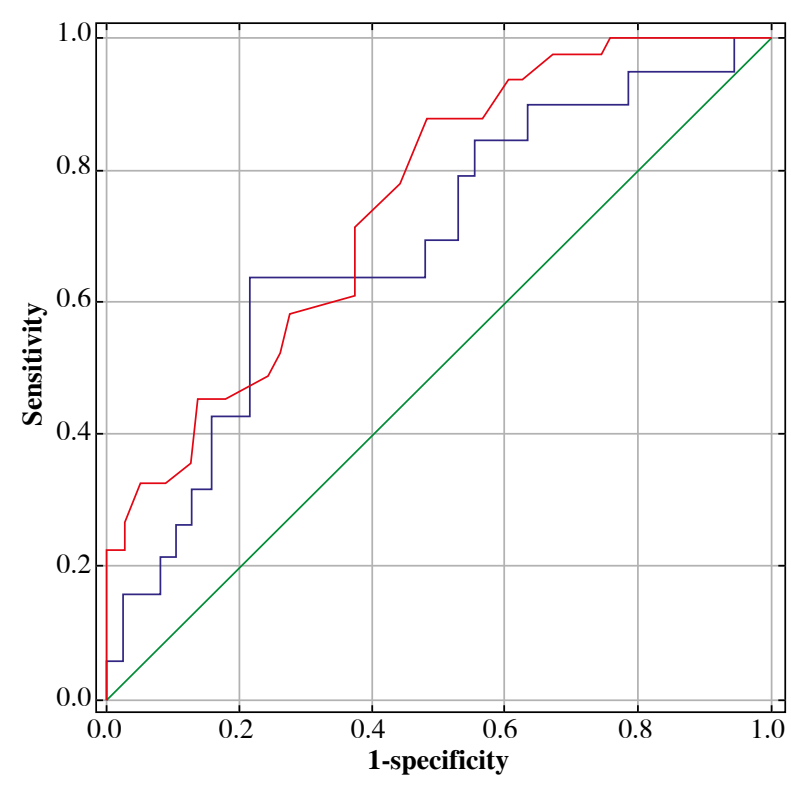

- sTNFR1 - APACHE II — Reference line

Fig. 8. ROC curves for APACHE II and concentrations of sTNFR1 in the serum $(\mathrm{pg} / \mathrm{ml})$ of patients treated in ICU due to severe infections

\section{Discussion}

Significant heterogeneity of the examined group of ICU patients is a common problem, which hinders the assessment of efficiency of new diagnostic methods and the treatment of acute infections. Patients treated in ICU vary considerably regarding recognition, course of an illness, aggravation of immune and metabolic disorders, and reactions to the treatment. Upset immune response based on changes in concentration of the chosen cytokines and proteins of the TLR4 receptor signalling pathways is an important diagnostic marker of a severe condition and infection. Early detection of immune disorders can significantly influence the choice of therapy, treatment results, and mortality.

The results of tests conducted in the study clearly indicate important differences in the concentrations of the majority of examined proteins, during innate immune response in patients treated in an ICU, and vital differences in concentrations of only some proteins in patients with diagnosed infections. In other studies, it was reported that changes in gene expression and concentrations of proteins related to innate immune response occur not only in patients with infections, but also in the process of SIRS reaction (systemic inflammatory response syndrome), reactions 
to injuries (caused by various factors, e.g., accident, extensive surgery, etc.) [28], burns [29], or cancers [30-32]. As it was concluded, the intensity of those changes, especially anti-inflammatory response, correlates with complications $[21,33]$.

The results of tests performed in our research suggest that an excessive activation of cells of the immune system leads to an increase in concentration of effectors of the TLR receptor signalling pathway, as it is confirmed by other authors $[34,35]$. Changes in the concentrations of proteins related to pro- and anti-inflammatory reaction were observed in the present study. In patients treated in the ICU, in comparison with the healthy ones, a significant increase in concentration of pro-inflammatory proteins (i.e., IL-6, sTNFR1, TNF- $\alpha$ ) was recorded, with simultaneous increase in concentration of cytokines with anti-inflammatory effect, such as IL-1Ra. Similar differences were observed in the case of patients with diagnosed infections, who constituted $46 \%$ of the examined group. Further research is required for an explanation of reasons and results of the decrease in concentration of adaptor protein MyD88 and the inhibitor protein A20 (proteins, which are important for TLR2 and TLR4 pathways). Other authors in tests on animal models proved that mice deprived of MyD88 genes were completely protected from organ injuries resulting from sepsis, which was confirmed by histological tests. However, a mice with deficiencies of TLR2 and TLR4, and the adaptor protein MyD88, reacted less efficiently to bacteria, and resulted in less severe inflammatory process, decrease of migration of neutrophils, increased growth of bacteria and thereby, weaker protection of kidney functions in comparison with wild mice [36]. The study of Peck-Palmer et al. showed that deletion of the MyD88 gene significantly weakened lymphocyte apoptosis $\mathrm{T}$ and $\mathrm{B}$ that was induced by sepsis but increased mortality [37]. In another research with mice, it was demonstrated that LPS and other ligands caused meningococcal sepsis, and it was confirmed that meningococcal LPS activated MyD88-dependent and TRIF-dependent pathways, yet ligands other than LPS activated only MyD88-dependent pathways [38]. Xu et al. study indicated that the MyD88 protein was regulated/inhibited by microRNA-149 [39]. In another study, it was concluded that MyD88 was the critical protein in the regulation of TLR pathway by microRNA. The aim of the greatest number of microRNA, with the miR-200 family, was the MyD88 protein, not TLR4, IRAK1, or TRAF6 [40, 41]. In tests with mice, it was observed that tolerance to endotoxins resulted in a limitation of excessive inflammatory reaction, re-programed response of macrophages to LPS, decreased expression of pro-inflammatory cytokines, and simultaneously increased expression of negative regulators of TLR4 pathway, including A20 [42]. In another study it was assumed that reactive forms of oxygen increase the expression of A20 in macrophages, which rises the tolerance to endotoxins. A new signalling pathway involving A20 (inhibitor of inflammatory reaction induced by LPS) was identified, which could significantly contribute to a new therapeutic strategy [43].

Comparison of the group with infections with the group without infections but treated in an ICU was an attempt to select an efficient marker of infection in intensive therapy conditions, which has been a subject of studies for decades. Even though in the course of infections, an increase (even multiple) in many proteins' concentration is observed, only few passes tests on significance. The presented research showed an increase in concentration of proteins sTNFR1, IL-1Ra, and IL-10, and a decrease in concentration of protein A20 and sTLR4. However, those differences were statistically significant only for proteins sTNFR1, sTLR4, and IL-10.

As a result of further analysis, a potential marker was selected that was efficient in differentiating an early response to an infection from other reasons responsible for hospitalization in the ICU. For sTNFR1, a significantly higher concentration in the group of patients with infections was observed in comparison with the rest of the patients treated in the ICU. Apart from a diagnostic value for severe infections, this protein appears to have a prognostic value; significantly higher concentrations were determined in the group of patients who deceased. Considerably higher concentrations of proteins in patients who deceased were also recorded for proteins IL-6, IL-10, and HSP70, which confirms prior research [21].

ROC analysis is a tool that can be used if a given parameter has a prognostic value and is able to define the cutoff point, above which the risk of death rises considerably. The possibility of conducting a laboratory test within first hours of ICU hospitalization and its interpretation based on the developed norms, allows us to establish a potential threat of severe complications and death. In the conducted ROC analysis, it was concluded that determining the concentration of protein STNFR1 is an effective tool with prognostic significance, especially in patients with infections, but only one of the studied proteins was statistically important. Whereas, in other patients treated in an ICU without infections, the effectiveness of determining IL-6 and HSP70 was confirmed; at the optimum cut-off point sensitivity of sTNFR1, capacity for predicting death was $91 \%$, and in terms of specificity, capacity for detecting cases of probable survival was $48 \%$. According to the research of Mikacenic et al. [44], the prognostic value of sTNFR1 can increase by binding this protein with IL-8 (creation of a multi-marker). Cohort studies indicate that multi-marker research, which takes into consideration the pathomechanism of severe infections, is a promising direction for development of sepsis diagnostics [45].

The effectiveness of determining IL-6 as a prognostic marker was also examined. IL-6 is a cytokine with approved diagnostic value. In the present study, it was 
concluded that the concentration of IL-6 in patients who deceased due to infections was significantly lower than in patients who survived. On the other hand, in patients who deceased due to other causes, the concentration of IL-6 was higher than in patients who survived. In the research of Bloos and Reinhart [46] and Mat-Nor et al. [47] it was indicated that IL-6 and PCT tests resulted in similar diagnostic values; however, those were higher than CRP test. IL-6 has a moderate diagnostic effectiveness in differentiating sepsis from non-infectious SIRS. Due to clinical issues, it is recommended to use IL-6 as a diagnostic support in confirming infections, and not for excluding infections in patients with SIRS. In this research, the predictive value of IL-6 was indicated (AUC $=0.7$ ), especially in combination with SOFA scale. In our research, IL-6 was proved to have a higher predictive value in patients without infections $(\mathrm{AUC}=0.736)$ than in those with infections (ROC analysis was statistically insignificant).

As presented, in assessing the risk of complications and death, an undeniably important role is still played by the APACHE II scale (AUC $=0.726$, sensitivity $69 \%$, specificity $68 \%$ ). However, due to a significant heterogeneity in the groups of patients treated in ICU and a high probability of the occurrence of severe infections, molecular tests are recommended allowing to detect an illness or assess the risk of its occurrence before clinical symptoms appear. It is well-known that the earlier immunomodulating treatment is implemented, the better the outcome. In the conducted statistical analysis of APACHE II marker, 27 points were considered as the optimal cut-off point, which correlated with the risk of death. However, a higher risk of death occurrence by other authors was observed at 17 points in the APACHE II scale [48]. In the studied group, in 140 (86\%) patients, the number of points was $\geq 17$.

It is worth emphasizing that examining the concentration of proposed proteins appears to be the optimal, earlier, and more sensitive marker than the acute phase protein (CRP) or procalcitonin (PCT), since the proteins of innate immune response stimulate the synthesis of CRP (e.g., IL-6 and TNF- $\alpha$ condition stimulate the synthesis of CRP) [49] and PCT (e.g., LPS, IL-1 $\beta$, IL-2, IL-6, and TNF- $\alpha$ induce secretion of PCT) [50]. It is also confirmed by our earlier study in a homogeneous group of patients with and without infections, who were operated due to colorectal cancer [51]. On the other hand, it was shown that in septic patients treated in an ICU during the first stage of response to an injury and infection, in leucocytes, an increasing expression of genes that code the proteins of early immune response could be a diagnostic marker [7, 52-54]. However, genetic tests are still poorly available.

One of the factors that could affect the interpretation of the study results was the patients' age. In studies with healthy donors, it was shown that the concentration of HMGB1 and Myd88 decreases with age, whereas only in case of MyD88, a negative correlation between the con- centration of protein and age was indicated, which was proven in our research [55].

The evaluation of studied markers was hindered by the fact that the patients arrived in ICUs within various time periods, and in spite of molecular test being performed on the biological material extracted within the first 24 hours of ICU hospitalization, the obtained results characterized early immune response, with various degrees of precision. In another study, it was reported that changes in concentrations of cytokines within the first 3-6 hours form the injury determine the process of immune response and differentiate its physiological course from the pathological one. In a later period, cytokine concentrations equalize between both groups of patients with positive and negative prognosis and maintain high figures for a few days [56].

\section{Conclusions}

Due to analysis, a marker was selected, which was most efficient in differentiating early responses to infections from other reasons for hospitalization in ICUs. For sTNFR1, significantly higher concentrations in the group of patients with infections were shown, in comparison with the rest of the patients treated in the ICU. Apart from diagnostic value for severe infections, this protein appears to have prognostic value; significantly higher concentrations were determined in the group of patients who deceased. In the ROC analysis, it was concluded that determining the concentration of protein sTNFR1 is a particularly effective tool, with prognostic value in the case of patients with infections, whereas in other patients treated in the ICU, efficiency of determining IL-6 was confirmed. In the future, multi-center clinical trials should be performed for multi-markers of severe infections in different groups of patients treated in ICUs, with regards to STNFR1.

\section{Acknowledgments}

This study was supported by the National Science Centre (NCN Poland, grant no. NN401103340) and the study was performed within the framework of research project conducted in the years 2016-2018, financed from the statutory grant received by the Faculty of Health Sciences of Warsaw Medical University ( NZT/PM2/16).

We would like to express our special gratitude for support in execution of the research to Mrs. Maria Kopacz.

The authors declare no conflict of interest.

\section{References}

1. Singer M, Deutschman CS, Seymour CW, et al. (2016): The Third International Consensus Definitions for Sepsis and Septic Shock (Sepsis-3). JAMA 315: 801-810. 
2. Mayr FB, Yende S, Angus DC (2014): Epidemiology of severe sepsis. Virulence 5: 4-11.

3. Fleischmann C, Hartmann M, Hartog CS, et al. (2015): Epidemiology of sepsis in Germany: incidence, mortality and associated costs of care 2007-2013. Intensive Care Med Exp 3: A50.

4. Kahn J, Le T, Angus D, et al. (2015): The Epidemiology of Chronic Critical Illness in the United States. Crit Care Med 43: 282-287.

5. Kübler A, Adamik B, Durek G, et al. (2015): Results of the severe sepsis registry in intensive care units in Poland from 2003-2009. Anaesthesiol Intensive Ther 47: 7-13.

6. Murphy TJ, Paterson HM, Mannick JA, et al. (2004): Injury, sepsis, and regulation of Toll-like receptor responses. J Leukoc Biol 75: 400-407.

7. Xiao W, Mindrinos MN, Seok J, et al. (2011): A genomic storm in critically injured humans. J Exp Med 208: 25812590.

8. Cuenca AG, Delano MJ, Kelly-Scumpia KM, et al. (2011): A Paradoxical Role for Myeloid-Derived Suppressor Cells in Sepsis and Trauma. Mol Med 17: 281-292.

9. Gentile LF, Cuenca AG, Efron PA, et al. (2012): Persistent inflammation and immunosuppression: a common syndrome and new horizon for surgical intensive care. J Trauma Acute Care Surg 72: 1491-1501.

10. Hawkins RB, Raymond SL, Stortz JA, et al. (2018): Chronic Critical illness and the Persistent inflammation, immunosuppression, and Catabolism Syndrome. Front Immunol 9: 1511.

11. Pierrakos C, Vincent J-L (2010): Sepsis biomarkers: a review. Crit Care 14: R15.

12. Hotchkiss RS, Opal S (2010): Immunotherapy for sepsis a new approach against an ancient foe. N Engl J Med 363: 87-89.

13. Tamayo E, Fernández A, Almansa R, et al. (2011): Pro- and anti-inflammatory responses are regulated simultaneously from the first moments of septic shock. Eur Cytokine Netw 22: 82-87.

14. Faix JD (2013): Biomarkers of sepsis. Crit Rev Clin Lab Sci 50: 23-36.

15. Biron BM, Ayala A, Lomas-Neira JL (2015): Biomarkers for Sepsis: What Is and What Might Be? Biomarker Insights 10: 7-17.

16. Jeong E, Lee JY (2011): Intrinsic and extrinsic regulation of innate immune receptors. Yonsei Med J 52: 379-392.

17. Opal SM, Laterre P-F, Francois B, et al. (2013): Effect of eritoran, an antagonist of MD2-TLR4, on mortality in patients with severe sepsis: the ACCESS randomized trial. JAMA 309: 1154-6210.

18. Rice TW, Wheeler AP, Bernard GR, et al. (2010): A randomized, double-blind, placebo-controlled trial of TAK-242 for the treatment of severe sepsis. Crit Care Med 38: 1685-1694.

19. Yuk J-M, Jo E-K (2011): Toll-like receptors and innate immunity. J Bacteriol Virol 41: 225-235.

20. Machado JR, Soave DF, da Silva MV, et al. (2014): Neonatal sepsis and inflammatory mediators. Mediators Inflamm 2014: 269681.

21. Gogos CA, Drosou E, Bassaris HP, et al. (2000): Pro- versus anti-inflammatory cytokine profile in patients with severe sepsis: a marker for prognosis and future therapeutic options. J Infect Dis 181: 176-180.

22. Wu H-P, Chen Ch-K, Chung K, et al. (2009): Serial cytokine levels in patients with severe sepsis. Inflamm Res 58: 385-393.
23. Andaluz-Ojeda D, Bobillo F, Iglesias V, et al. (2012): A combined score of pro- and anti-inflammatory interleukins improves mortality prediction in severe sepsis. Cytokine 57: 332-336.

24. Bone RC, Balk RA, Cerra FB, et al. (1992): Definitions for Sepsis and organ failure and guidelines for the use of innovative therapies in sepsis. The ACCP/SCCM Consensus Conference Committee American College of Chest Physicians/ Society of Critical Care Medicine. Chest 101: 1644-1655.

25. Levy MM, Fink MP, Marshall JC, et al. (2003): 2001 SCCM/ ESICM/ACCP/ATS/SIS International Sepsis Definitions Conference. Crit Care Med 31: 1250-1256.

26. Dellinger RP, Levy MM, Rhodes A, et al. (2013): Surviving Sepsis Campaign: International Guidelines for Management of Severe Sepsis and Septic Shock, 2012. Intensive Care Med 39: 165-228.

27. Zweig MH, Campbell G (1993): Receiver-operating characteristic (ROC) plots: a fundamental evaluation tool in clinical medicine. Clin Chem 39: 561-577.

28. Bińkowska AM, Michalak G, Słotwiński R (2015): Current views on the mechanisms of immune responses to trauma and infection. Cent Eur J Immunol 40: 206-216.

29. Hur J, Yang HT, Chun W, et al. (2015): Inflammatory Cytokines and Their Prognostic Ability in Cases of Major Burn Injury. Ann Lab Med 335: 105-110.

30. Lin W-W, Karin M (2007): A cytokine-mediated link between innate immunity, inflammation, and cancer. J Clin Invest 117: 1175-1183.

31. Williams AE, Perry MM, Moschos SA, et al. (2008): Role of miRNA-146a in the regulation of the innate immune response and cancer. Biochem Soc Trans 36: 1211-1215.

32. Cui J, Chen Y, Wang HY, et al. (2014): Mechanisms and pathways of innate immune activation and regulation in health and cancer. Hum Vaccin Immunother 10: 3270-3285.

33. de Pablo R, Monserrat J, Reyes E, et al. (2011): Mortality in patients with septic shock correlates with anti-inflammatory but not proinflammatory immunomodulatory molecules. J Intensive Care Med 26: 125-132.

34. Kumar H, Kawai T, Akira S (2011): Pathogen recognition by the innate immune system. Int Rev Immunol 30: 16-34.

35. Kumar S, Ingle H, Prasad DVR, Kumar H (2013): Recognition of bacterial infection by innate immune sensors. Crit Rev Microbiol. 39: 229-246.

36. Castoldi A, Braga TT, Correa-Costa M, et al. (2012): TLR2, TLR4 and the MYD88 Signaling Pathway Are Crucial for Neutrophil Migration in Acute Kidney Injury Induced by Sepsis. PLoS One 7: e37584.

37. Peck-Palmer OM, Unsinger J, Chang KC, et al. (2008): Deletion of MyD88 markedly attenuates sepsis-induced T and B lymphocyte apoptosis but worsens survival. J Leukoc Biol 83: 1009-1018.

38. Plant L, Wan H, Jonsson A-B, (2006): MyD88-Dependent Signaling Affects the Development of Meningococcal Sepsis by Nonlipooligosaccharide Ligands. Infect Immun 74: 3538-3546.

39. Xu G, Zhang Z, Xing Y, et al. (2014): MicroRNA-149 negatively regulates TLR-triggered inflammatory response in macrophages by targeting MyD88. J Cell Biochem 115: 919-927.

40. Wendlandt EB, Graff JW, Gioannini TL, et al. (2012): The role of MicroRNAs miR-200b and miR-200c in TLR4 signaling and NF- $\kappa B$ activation. Innate Immun 18: 846-855.

41. Essandoh K, Fan G-Ch (2014): Role of extracellular and intracellular microRNAs in sepsis. Biochim Biophys Acta 1842: 2155-2162. 
42. Xiong Y, Medvedev AE (2011): Induction of endotoxin tolerance in vivo inhibits activation of IRAK4 and increases negative regulators IRAK-M, SHIP-1, and A20. J Leukoc Biol 90: 1141-1148.

43. Uddin J, Joe Y, Kim S-K, et al. (2016): IRG1 induced by heme oxygenase-1/carbon monoxide inhibits LPS-mediated sepsis and pro-inflammatory cytokine production. Cell Mol Immunol 13: 170-179.

44. Mikacenic C, Price BL, Hajru-Baker S, et al. (2017): A Two-Biomarker Model Predicts Mortality in the Critically Illwith Sepsis. Am J Respir Crit Care Med 196: 1004-1011.

45. Wong HR, Lindsell ChJ, Pettilä V, et al. (2014): A multibiomarker-based outcome risk stratification model for adult septic shock. Crit Care Med 42: 781-789.

46. Bloos F, Reinhart K (2014): Rapid diagnosis of sepsis. Virulence 5: 154-160.

47. Mat-Nor MB, Md Ralib A, Abdulah NZ, et al. (2016): The diagnostic ability of procalcitonin and interleukin- 6 to differentiate infectious from noninfectious systemic inflammatory response syndrome and to predict mortality. J Crit Care 33: 245-251.

48. Giamarellos-Bourboulis EJ, Norrby-Teglund A, Mylona V, et al. (2012): Risk assessment in sepsis: a new prognostication rule by APACHE II score and serum soluble urokinase plasminogen activator receptor. Crit Care 16: R149.

49. Sproston NR, Ashworth JJ (2018): Role of C-Reactive Protein at Sites of inflammation and infection. Front Immunol 9: 754.

50. Linscheid P, Seboek D, Nylen ES, et al. (2003): In vitro and in vivo calcitonin I gene expression in parenchymal cells: A novel product of human adipose tissue. Endocrinology 144: 5578-5584.

51. Słotwiński R, Olszewski WL, Chaber A, et al. (2002): The Soluble Tumor Necrosis Factor Receptor I Is an Early Predictor of Local Infective Complications After Colorectal Surgery. J Clin Immunol 22: 289-296.

52. Cuenca AG, Gentile LF, Lopez MC, et al. (2013): Development of a genomic metric that can be rapidly used to predict clinical outcome in severely injured trauma patients. Crit Care Med 41: 1175-1185.

53. Wong HR (2013): Genome-wide expression profiling in pediatric septic shock. Pediatr Res 73: 564-599.

54. Słotwiński R, Sarnecka A, Dąbrowska A, et al. (2015): Innate immunity gene expression changes in critically ill patients with sepsis and disease-related malnutrition. Cent Eur J Immunol 40: 311-324.

55. Fu G-X, Chen AF, Zhong Y, et al. (2016): Decreased serum level of HMGB1 and MyD88 during human aging progress in healthy individuals. Aging Clin Exp Res 28: 175-180.

56. Binkowska AM, Michalak G, Pilip S, et al. (2018): The diagnostic value of early cytokine response in patients after major trauma - preliminary report. CentEur J Immunol 43: 33-41. 